\title{
Preface to the $4^{\text {th }}$ English edition
}

Everything which has been said in the preface to the first German, as well as in the first to third English editions, still holds and essentially does not need any addition or correction. In this revised fourth edition in English, the manuscript has been updated and various recent aspects of energetic materials have been added:

(i) Some errors, which were unfortunately present in the third edition, have been corrected, and the references have also been updated where appropriate.

(ii) The chapters on shaped charges, visible pyrotechnics, smokes (addition of $\mathrm{P}_{3} \mathrm{~N}_{5}$ ), primary explosives (MTX-1), composite and double-base propellants, and Gurney energy have been updated.

(iii) Four new chapters on Electric Detonators (5.4), Detonation velocity from Laser Induced Air Shock (9.7), Thermally Stable Explosives (9.8), and Explosive Welding (13.5) have been added.

In addition to the people thanked in the German and first three English editions, the author would like to thank Professor Dr. Mohammad H. Keshavarz, Dr. Tomasz Witkowski, Col. Dr. Ahmed Elbeih, Cpt. Mohamed Abd-Elghany, M.Sc. and Lt. Andreea Voicu, M.Sc. for many inspired discussions.

Munich, July 2017

Thomas M. Klapötke 